\title{
Stygofauna diversity and distribution in Eastern Australian cave and karst areas
}

\author{
Mia E. Thurgate ${ }^{1 *}$, Jane S. Gough ${ }^{2}$, Arthur K. Clarke ${ }^{3}$, Peter Serov and Andy Spate ${ }^{2}$ \\ ${ }^{1}$ Jenolan Caves Reserve Trust, Locked Bag, Jenolan Caves, New South Wales 2790, Australia \\ e-mail: karst@jenolancaves.org.au \\ ${ }^{2}$ NSW National Parks and Wildlife Service, PO Box 2115, Queanbeyan, New South Wales 2620, Australia \\ ${ }^{3}$ School of Zoology, University of Tasmania, GPO Box 252-05, Hobart, Tasmania 7001, Australia \\ ${ }^{4}$ Centre for Natural Resources, Biodiversity and Conservation Unit, University of New England, PO Box U245. \\ Armidale, New South Wales 2351, Australia \\ * For correspondence
}

\begin{abstract}
This paper reviews the diversity and distribution of the stygofauna of Eastern Australia on a regional basis. Most of the stygofauna is concentrated in the highland karsts of New South Wales and Tasmania. Two hundred and thirty-eight taxa are present and amphipods, syncarids and hydrobiid gastropods are the dominant and most widespread groups. Nearly half of the total fauna are stygobites (82 taxa) and stygophiles (34 taxa). Also present are taxa with Gondwanan and Pangaean affinities, taxa that are phylogenetic and distributional relicts, and locally endemic taxa. Diversity and distribution at the local karst scale is also discussed using a case study of Wombeyan Caves, one of the richest stygofauna sites in Eastern Australia. The paper concludes with suggestions for further research.
\end{abstract}

\section{INTRODUCTION}

The presence of a diverse global stygofauna (fauna inhabiting groundwater environments) has led to groundwater ecology becoming a major discipline of scientific endeavour (Gibert et al., 1994), particularly in the Northern Hemisphere. In terms of global composition, crustaceans dominate the fauna, there is a paucity of insects, and gastropods are regionally significant (Botosaneanu, 1986; Culver and Sket, 2000; Sket, 1999). The diversity of these groundwater ecosystems was recently highlighted by the identification of stygofauna 'hotspots' in North America and Europe (Culver and Sket, 2000).

Despite considerable continental aridity and a paucity of cave and karst areas by world standards, Australia has been identified as a regional centre of stygofauna diversity (Holsinger, 1993; Knott, 1986; Williams, 1986). Support for this statement arises from research in Western Australia, particularly in Cape Range, Barrow Island and Yanchep (e.g. Humphreys, 2000a; Jasinska and Knott, 2000). The two richest sites in the world for stygal amphipods are the Ethel Gorge calcrete and Barrow Island, both in northwestern Australia (Humphreys, 2001; Bradbury, 2000). There are also more stygal dytiscid beetles in the Yilgarn region (southwestern Australia) than in the remainder of the world combined (Humphreys, 2001). Less attention has been paid to the stygofauna of Eastern Australia (defined herein as east of $138^{\circ}$ longitude) but surveys suggest this is also an important region of stygofauna diversity (Eberhard et al., 1991; Eberhard and Spate, 1995).

This paper synthesises the available information on the stygofauna of Eastern Australia inhabiting karst and cave areas. We describe patterns in composition, diversity and distribution focussing particularly on the crustacean and molluscan fauna of New South Wales and Tasmania. Our intention is to highlight the stygofauna of Eastern Australia, draw attention to what is known of its significance, and encourage further discussion and research.

\section{METHODS AND SOURCES OF INFORMATION}

The information presented in this paper is based on several databases, unpublished reports and records of the authors'. Published information is also used for Tasmania (Eberhard et al., 1991; Clarke, 1997), New South Wales (Eberhard and Spate, 1995; Bradbury and Williams, 1997b) and South Australia (Zeidler, 1983; Thurgate, 1995). Details of the locations of specimens and the status of taxonomic determinations are available from the authors.

Most karst and cave areas in Eastern Australia have been cursorily sampled, although a few selected areas in Tasmania (e.g. Ida Bay, Mole Creek) and New South Wales (e.g. Wombeyan, Jenolan) have been more intensively surveyed. Surveys have employed a mixture of techniques 

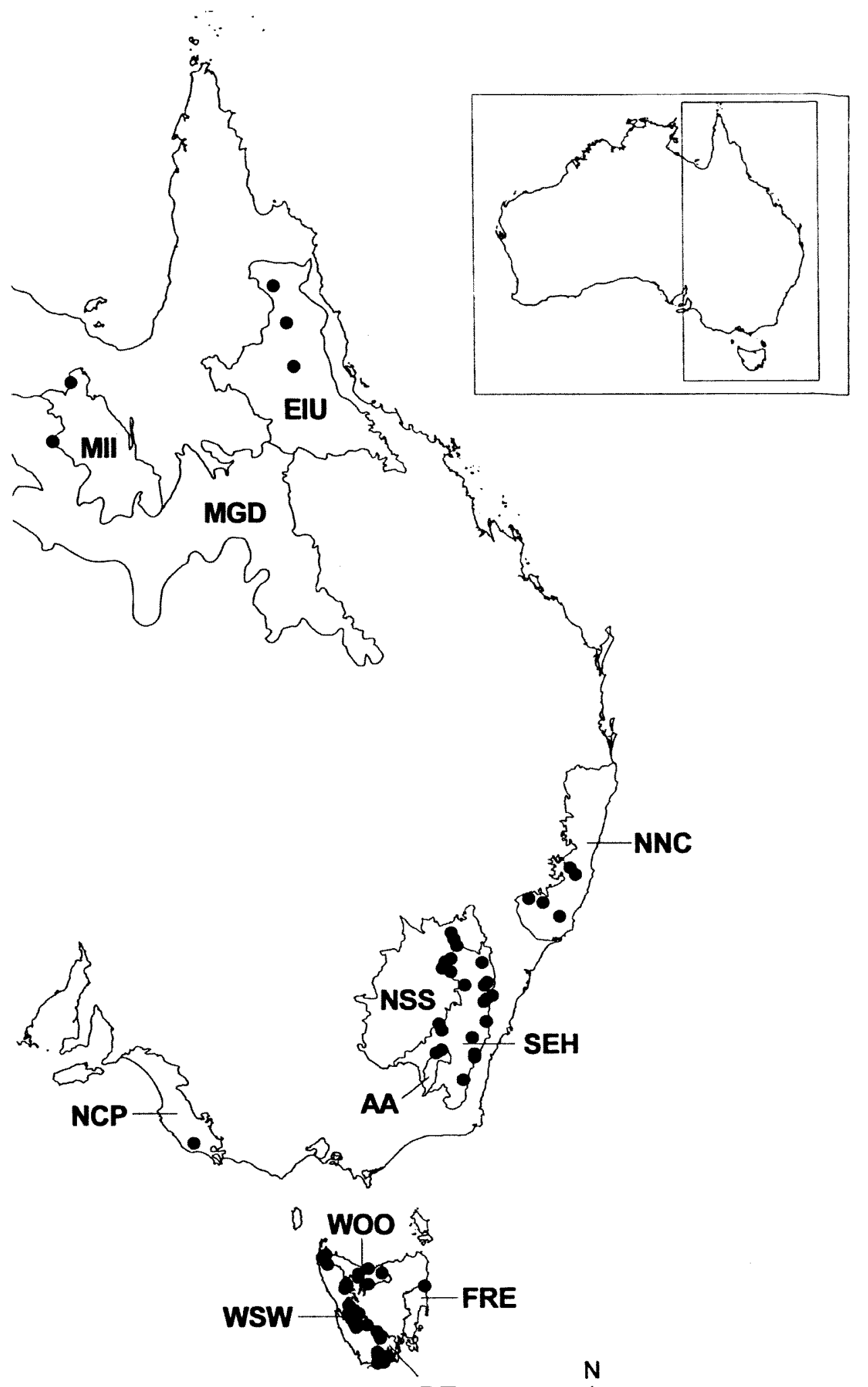

$250 \quad 0 \quad 250 \quad 500 \mathrm{~km}$

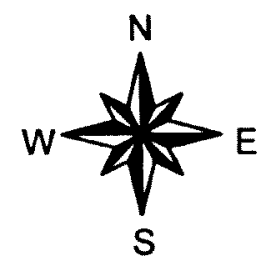

Figure 1 Distribution of stygofauna sites in Eastern Australia. Each dot on the map represents one or more karst areas. Boundaries for IBRA regions are also shown and follow Thackway and Cresswell (1995). Codes for IBRA regions are given in Table 1, except for MII (Mount Isa Inlier) and MGD (Mitchell Grass Downs). These latter two regions are not included in Table 1 as the diversity and composition of their stygofauna is completely undetermined. 
including active searching, nets and aspirators, and trapping with modified baited 'yabbie' pots (Eberhard et al., 1991; Eberhard and Spate, 1995; Clarke, 1997).

Much of the stygofauna is undetermined, but we have included information on these taxa to give a more complete indication of the diversity of these ecosystems. Where multiple specimens have not been clearly assigned to a particular genus or species, we have treated these as belonging to a single taxon. Given the distribution patterns discussed below (i.e. highly localised with many endemics), improved taxonomic information will undoubtedly result in an overall increase in diversity.

\section{Nature and Extent of Karst Areas}

The karsts of Eastern Australia are not uniformly distributed (Figure 1). Instead, they form a series of scattered outcrops that are concentrated in the southeast of Eastern Australia. The distribution of karst styles broadly corresponds to the biogeographic region boundaries developed under the Interim Biogeographic Regionalisation for Australia (IBRA: Thackway and Cresswell, 1995). These regions (Figure 1) are based on similarities in surface climate, geology, landform and biological attributes. We use the IBRA regions as an organisational framework for discussing the biogeography of the stygofauna, and it is not our intention to infer causality.

Most of the Eastern Australian karsts are of small size with limited surface expression (Table 1). Exceptions to this pattern are found in the extensive Mitchell Grass Downs and Naracoorte Coastal Plain Regions (Figure 1) where the karsts form broad, undulating plains in flat-bedded rock. Many of the caves in these regions have deep open shafts or sinkholes at their entrance. Most caves at Camooweal (Mitchell Grass Downs Region) are relictual and are perched above the water table for much of the year. In the Mount Gambier karst (Naracoorte Coastal Plain Region) groundwater is present at shallow depths in many caves.

In the Einasleigh Uplands Region, the karsts are residual tropical forms (karst towers) rising above the surrounding plains. They formed during the wetter conditions of the Tertiary (Jennings, 1982). Numerous individual towers are distributed over several hundred kilometres. Subdued tower karsts are also found in the North Coast Region, and these developed in the Cretaceous (Osborne and Branagan, 1988). This region is a transition zone between the tropical karsts described above and temperate karsts described below. Few caves extend to groundwater in either of these regions.

At least 90 small karst areas are widely scattered in the South Western Slopes, South East Highlands and Australian Alps Regions of New South Wales (Figure 1). Often these are ancient karsts, some of which developed in the Permian (Osborne and Branagan, 1988; Osborne, 1993, 1999). These karst areas are impounded, that is, surrounded by higherlying non-carbonate terrains so groundwater systems are generally small and discontinuous. Approximately 80 small karst areas are located in the Woolnorth, West and South West and D'Entrecasteaux Regions of Tasmania, and are of a similar age and style to those of southeast New South Wales, but are more extensive and deeper systems (Kiernan, 1995). In both states, the karsts are found throughout a range of climatic and altitudinal gradients.

The impounded karsts of New South Wales and Tasmania are complex systems, and many of them have experienced multiple phases of karstification interspersed with periods of marine transgression, burial, infilling and exhumation (Osborne and Branagan, 1988; Osborne, 1993, 1999; Clarke, 1995). In addition, many karst areas of Tasmania lie

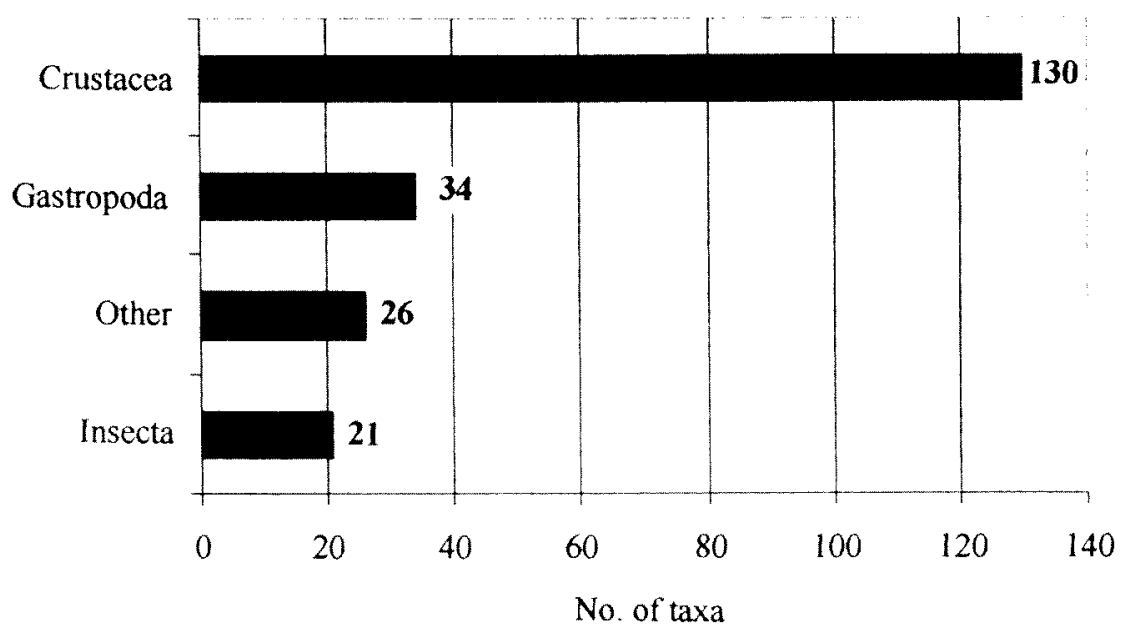

Figure 2 Composition of stygofauna in Eastern Australia. The group designated as 'other' includes protozoans, turbellarians, oligochaetes, nematomorphans, arachnids and bivalves. 
Table 1 Karst area characteristics and associated stygofauna families occurring within IBRA regions as defined by Thackway and Cresswell (1995). Representative sites include locations in New South Wales and Tasmania with a high stygofauna diversity (ie more than 10 taxa present). Families with five or more taxa present in a given IBRA region are also indicated.

\begin{tabular}{|c|c|c|c|}
\hline $\begin{array}{l}\text { IBRA Region } \\
\text { (IBRA Code) }\end{array}$ & Location, karst styles and climatic regime ${ }^{1}$ & $\begin{array}{l}\text { Representative sites } \\
\text { (Total no. taxa) }\end{array}$ & Characteristic faunal elements \\
\hline $\begin{array}{l}\text { Einasleigh } \\
\text { Uplands (EIU) }\end{array}$ & $\begin{array}{l}\text { QLD: Numerous bluffs (tower karst) over several hundred } \\
\text { kilometres. Watertable below caves during dry season except for } \\
\text { a few limited sites. Extensive lava tube complex with subterranean } \\
\text { groundwater pools and springs. Tropical, seasonally moist/arid. }\end{array}$ & $\begin{array}{l}\text { Mitchell-Palmer (1), Chillagoe (1), } \\
\text { Undara Lava Tubes (1) }\end{array}$ & Paramelitidae \\
\hline $\begin{array}{l}\text { North Coast } \\
\text { (NNC) }\end{array}$ & $\begin{array}{l}\text { NSW: Impounded karsts throughout landscape - most relictual and } \\
\text { dry. A few caves reach to groundwater, some small stream systems. } \\
\text { Warm temperate, summer rainfall. }\end{array}$ & $\begin{array}{l}\text { Stockyard Creek (4), Timor (3), } \\
\text { Pigna Barney (3), Willi Willi (1) }\end{array}$ & $\begin{array}{l}\text { Family nov. (Anaspidacea), } \\
\text { Eusiridae, Neoniphargidae }\end{array}$ \\
\hline $\begin{array}{l}\text { South Western } \\
\text { Slopes (NSS) }\end{array}$ & $\begin{array}{l}\text { NSW: Impounded (sometimes extensive) karsts with both relictual } \\
\text { caves and groundwater systems. Cool to warm temperate, uniform } \\
\text { but highly variable rainfall. }\end{array}$ & $\begin{array}{l}\text { Bowan Park (4), Wellington (3), } \\
\text { Bakers Swamp (2), Canomodine (1) }\end{array}$ & $\begin{array}{l}\text { Neoniphargidae (5), Psammaspididae (5), } \\
\text { Janiridae }\end{array}$ \\
\hline $\begin{array}{l}\text { South Eastern } \\
\text { Highlands (SEH) }\end{array}$ & $\begin{array}{l}\text { NSW/VIC: Impounded karsts with both relictual caves and active } \\
\text { stream/groundwater systems. Cool temperate, highly variable } \\
\text { winter rainfall. }\end{array}$ & $\begin{array}{l}\text { Wombeyan (40), Jenolan (15) Wee } \\
\text { Jasper (6), Colong ( } 3 \text { ) }\end{array}$ & $\begin{array}{l}\text { Neoniphargidae (14), Eusiridae, } \\
\text { Psammaspididae (5), Phreatoicidae, } \\
\text { Glacidorbidae, Hydrobiidae }\end{array}$ \\
\hline $\begin{array}{l}\text { Australian Alps } \\
\text { (AA) }\end{array}$ & $\begin{array}{l}\text { NSW/VIC: Impounded karsts with both relictual caves and active } \\
\text { stream/groundwater systems. Cool/cold temperate, variable } \\
\text { rainfall regime. Possibly influenced by periglacial conditions } \\
\text { during glacial maxima. }\end{array}$ & $\begin{array}{l}\text { Cooleman Plains (10), } \\
\text { Yarrangobilly (7) }\end{array}$ & $\begin{array}{l}\text { Eusiridae, Neoniphargidae, } \\
\text { Psammaspididae, Janiridae, Ancylidae, } \\
\text { Glacidorbidae }\end{array}$ \\
\hline $\begin{array}{l}\text { Naracoorte Coastal } \\
\text { Plain (NCP) }\end{array}$ & $\begin{array}{l}\text { SA/VIC: Flat bedded karst with many "windows" reaching down } \\
\text { to regional groundwater. Subject to major water level change } \\
\text { through glacial/non-glacial cycles. Cool temperate, moist to } \\
\text { semi-arid rainfall regime. }\end{array}$ & $\begin{array}{l}\text { Mount Gambier area }(>40, \text { majority } \\
\text { epigean species in springs } \\
\text { and cenotes) }\end{array}$ & $\begin{array}{l}\text { Ceinidae, Paramelitidae, Koonungidae, } \\
\text { Hydrobiidae, Planorbidae }\end{array}$ \\
\hline Woolnorth (WOO) & $\begin{array}{l}\text { TAS: Many areas of impounded karsts with active } \\
\text { stream/groundwater systems. Cool temperate, moist. Some } \\
\text { influenced by periglacial conditions during glacial maxima. }\end{array}$ & $\begin{array}{l}\text { Mole Creek (19), Gunns Plains (16), } \\
\text { Loongana (16), Trowutta (9) }\end{array}$ & $\begin{array}{l}\text { Paramelitidae (11), Neoniphargidae, } \\
\text { Koonungidae, Amphisopidae, Phreatoicidae, } \\
\text { Hydrobiidae (7) }\end{array}$ \\
\hline $\begin{array}{l}\text { West and South } \\
\text { West (WSW) }\end{array}$ & $\begin{array}{l}\text { TAS: Many areas of impounded karsts with active } \\
\text { stream/groundwater systems. Cool/cold temperate, very moist. } \\
\text { Many karsts influenced by periglacial conditions during } \\
\text { glacial maxima. }\end{array}$ & $\begin{array}{l}\text { Franklin (14), Bubs Hill (12), Lower } \\
\text { Andrew (10), Precipitous Bluff (10) }\end{array}$ & $\begin{array}{l}\text { Paramelitidae (15), Eusiridae, } \\
\text { Neoniphargidae, Koonungidae, } \\
\text { Phreatoicidae, Janiridae, Hydrobiidae (15) }\end{array}$ \\
\hline $\begin{array}{l}D^{\prime} \text { Entrecasteaux } \\
\text { (DE) }\end{array}$ & $\begin{array}{l}\text { TAS: Many areas of impounded karsts with active } \\
\text { stream/groundwater systems. Cool/cold temperate, very moist. } \\
\text { Some influenced by periglacial conditions during glacial maxima. }\end{array}$ & $\begin{array}{l}\text { Ida Bay (33), Junee-Florentine (19), } \\
\text { Hastings (9), Cracroft (6) }\end{array}$ & $\begin{array}{l}\text { Paramelitidae (13), Eusiridae, Anaspididae, } \\
\text { Janiridae, Hydrobiidae (11) }\end{array}$ \\
\hline Freycinet (FRE) & $\begin{array}{l}\text { TAS: A few small impounded karsts with active stream/ } \\
\text { groundwater systems. Cool temperate, variable winter rainfall. }\end{array}$ & Gray (3) & Paramelitidae, Psammaspididae \\
\hline
\end{tabular}


Table 2 Composition of major stygofauna groups in Eastern Australia ${ }^{1}$. Figures in brackets indicate undetermined taxa that are probably stygobites or stygophiles. Species that have only been collected from a single karst area or single cave are considered endemic.

\begin{tabular}{|c|c|c|c|c|c|}
\hline Taxa & $\begin{array}{c}\text { Total No. } \\
\text { Genera }\end{array}$ & $\begin{array}{l}\text { Total No. } \\
\text { Species }\end{array}$ & $\begin{array}{c}\text { No. } \\
\text { Stygobites }\end{array}$ & $\begin{array}{c}\text { No. } \\
\text { Stygophiles }\end{array}$ & $\begin{array}{l}\text { Total No. } \\
\text { Endemics }\end{array}$ \\
\hline $\begin{array}{l}\text { Amphipoda }{ }^{2} \\
\text { Paramelitidae } \\
\text { Neoniphargidae } \\
\text { Other families }\end{array}$ & $\begin{array}{l}10 \\
10 \\
5\end{array}$ & $\begin{array}{c}35 \\
23 \\
8\end{array}$ & $\begin{array}{c}21 \\
20 \\
1\end{array}$ & $\begin{array}{c}9(5) \\
3 \\
3\end{array}$ & $\begin{array}{c}18 \\
21 \\
3\end{array}$ \\
\hline $\begin{array}{l}\text { Syncarida } \\
\text { Psammaspididae } \\
\text { Koonungidae } \\
\text { Anaspididae } \\
\text { Other families }\end{array}$ & $\begin{array}{l}2 \\
4 \\
1 \\
2\end{array}$ & $\begin{array}{l}13 \\
5 \\
3 \\
3\end{array}$ & $\begin{array}{l}13 \\
3 \\
1 \\
3\end{array}$ & $\begin{array}{l}- \\
(2) \\
2 \\
-\end{array}$ & $\begin{array}{l}11 \\
3 \\
1 \\
3\end{array}$ \\
\hline $\begin{array}{l}\text { Decapoda } \\
\text { Parastacidae } \\
\text { Other families }\end{array}$ & $\begin{array}{l}7 \\
2\end{array}$ & $\begin{array}{c}17 \\
2\end{array}$ & - & $\begin{array}{l}3 \\
1\end{array}$ & $\begin{array}{l}6 \\
1\end{array}$ \\
\hline $\begin{array}{l}\text { Isopoda } \\
\text { Phreatoicidae } \\
\text { Janiridae } \\
\text { Amphisopidae }\end{array}$ & $\begin{array}{l}3 \\
2 \\
1\end{array}$ & $\begin{array}{l}5 \\
5 \\
1\end{array}$ & $\begin{array}{l}3 \\
4 \\
1\end{array}$ & $\begin{array}{l}(2) \\
1 \\
-\end{array}$ & $\begin{array}{l}1 \\
1 \\
1\end{array}$ \\
\hline Other Crustacea & 6 & 10 & $2(5)$ & (1) & - \\
\hline $\begin{array}{l}\text { Gastropoda }^{3} \\
\text { Hydrobiidae } \\
\text { Other families }\end{array}$ & $\begin{array}{l}7 \\
8\end{array}$ & $\begin{array}{c}25 \\
9\end{array}$ & $\begin{array}{c}6(2) \\
-\end{array}$ & $\begin{array}{l}9 \\
-\end{array}$ & $\begin{array}{c}12 \\
6\end{array}$ \\
\hline $\begin{array}{l}\text { Coleoptera } \\
\text { Dytiscidae } \\
\text { Other families }\end{array}$ & $\begin{array}{l}2 \\
2\end{array}$ & $\begin{array}{l}4 \\
5\end{array}$ & - & $\begin{array}{c}2(1) \\
-\end{array}$ & - \\
\hline $\begin{array}{l}\text { Trichoptera } \\
\text { Philopotamidae } \\
\text { Other families }\end{array}$ & $\begin{array}{l}1 \\
2\end{array}$ & $\begin{array}{l}2 \\
2\end{array}$ & - & $\begin{array}{l}1 \\
-\end{array}$ & $\begin{array}{l}- \\
-\end{array}$ \\
\hline Other Insecta & 11 & 15 & - & - & - \\
\hline Other taxa & 16 & 38 & $4(1)$ & (2) & 10 \\
\hline Totals & 104 & 230 & $82-90$ & $34-47$ & 98 \\
\hline
\end{tabular}

1 Based on the New South Wales Cave Invertebrate database (Eberhard and Spate, 1995), Tasmanian RFA database (Clarke, 1997), Thurgate (1995) and unpublished records.

2 Additional information from Barnard and Williams (1995), Williams and Barnard (1988) and J. Bradbury (personal communication, 2000).

3 Additional information from W. Ponder (personal communication, 1999).

marginal to or within areas that were covered by glaciers and infilled by glacial sediments during the late Cainozoic (Eberhard et al., 1991; Kiernan, 1990; Clarke, 1995).

\section{COMPOSITION AND DIVERSITY OF STYGOFAUNA}

\section{Composition}

Table 2 summarises the overall composition of the main stygal orders and families across Eastern Australia. Crustaceans are the dominant and most widespread group (Figure 2), and are composed primarily of amphipods. The remainder of the crustacean fauna includes syncarids, decapods, isopods, copepods and ostracods. Gastropods, an important component of the stygofauna (Figure 2), are dominated by Hydrobiidae, and also include Ancylidae and Glacidorbidae. Insects are of minor significance in the stygofaunas of individual karst areas. Less well represented taxa include turbellarians, oligochaetes, arachnids, hydrozoans, nematomorphans and protozoans.

The stygofauna of Eastern Australia includes taxa with varying degrees of dependence on the subterranean habitat (Table 2). Stygobites are obligate and specialised subterranean forms that 
often display some degree of troglomorphy (adaptation to subterranean life). Stygophiles are facultative forms that seek out and utilise groundwater environments. Finally, stygoxenes are epigean forms that occur accidentally and that show no particular affinity to groundwaters (all based on Humphreys, 2000b).

Most stygobites are crustaceans, with amphipods and syncarids having the highest diversity, while amphipods and hydrobiid snails (Table 2) dominate the stygophiles. The decapods and insects also include some stygophiles but most appear to be stygoxenes. The high proportions of stygobites amongst some families (eg. Paramelitidae, Neoniphargidae and Psammaspididae), as well as high proportions of local endemism (Table 2) suggests strong selection pressures or long periods of isolation in subterranean waters for this fauna.

A component of the Eastern Australian stygofauna is composed of taxa with Gondwanan and Pangaean affinities (Barnard and Karaman, 1984; Williams and Barnard, 1988; Wilson and Wägele, 1994; Bradbury and Williams, 1997a; Wilson and Johnson, 1999). These are found mostly within the higher Crustacea (Table 3). A number of these crustaceans are phylogenetic and distributional relicts, as are the hydrobiid gastropods (Hamilton-Smith and Eberhard, 2000), and so are valuable for biogeographical and evolutionary research. The presence of these families in the cave waters of Eastern Australia suggests some karst areas have acted as refuges (sensu Humphreys, 2000c) for stygofauna.

\section{Diversity}

Two hundred and thirty stygal species have been recorded from Eastern Australia, and crustaceans comprise up to $57 \%$ of the total. Within the crustaceans, 130 species from 55 genera have been recorded. The most diverse crustacean families are the paramelitid, neoniphargid and psammaspid amphipods (Table 2). The hydrobiid snails are also a rich group ( 25 species from 7 genera) with a diversity that is only surpassed by the paramelitid amphipods ( 35 species from 10 genera).

Over one third of the stygofauna from Eastern Australia are obligate groundwater animals. At least 82 stygobite taxa have been recorded and they occur in 46 of the 71 karst areas that contain stygofauna (Table 2). Most of these taxa are found within the four families mentioned above. A further $15-20 \%$ of the stygofauna are stygophiles, the remainder of the fauna are stygoxenes.

Most cave and karst areas in Eastern Australia have a low richness and abundance of stygofauna by world standards (Culver and Sket, 2000). Few mainland karsts support more than 10 stygal taxa. Wombeyan (40 taxa), Jenolan (15 taxa) and Cooleman Plain (10 taxa) are the exceptions in New South Wales. The Mount Gambier area in South Australia contains over 40 stygal taxa. Tasmania has nine karst areas (Table 1) with this level of diversity including Ida Bay (33 taxa), Junee-Florentine (19 taxa) and Mole Creek (19 taxa).

In mainland karsts, diversity at the level of individual caves is low. Most caves support less than five taxa, and it is rare for more than two obligate taxa to be present in the same cave. In contrast, at least 13 Tasmanian caves contain five or

Table 3 The origins and present global distribution of major stygal crustacean families collected from Eastern Australia. Data based on Banarescu (1990a and 1990b) unless otherwise indicated.

\begin{tabular}{|c|c|c|}
\hline Order and Family & Affinities & Present Distribution \\
\hline \multicolumn{3}{|l|}{ Amphipoda } \\
\hline Neoniphargidae & East Pangaea $^{1}$ & Australia \\
\hline Paramelitidae & East Gondwana & Australia, South Africa, South America \\
\hline Ceinidae & East Gondwana ${ }^{2}$ & Australia, New Zealand, South Africa \\
\hline \multicolumn{3}{|l|}{ Syncarida } \\
\hline Psammaspididae & Gondwana & Australia \\
\hline Koonungidae & Gondwana & Australia \\
\hline Anaspididae & Gondwana & Australia \\
\hline Stygocarididae & Gondwana & Australia, New Zealand, South America \\
\hline Parabathynellidae & Gondwana & Cosmopolitan \\
\hline \multicolumn{3}{|l|}{ Isopoda } \\
\hline Phreatoicidae & East Gondwana & Australia, New Zealand, South Africa, India \\
\hline Janiridae & Gondwana $^{3}$ & Australia, South America \\
\hline Amphisopidae & East Gondwana & Australia, New Zealand, South Africa, India \\
\hline
\end{tabular}

1 Bradbury and Williams (1997a).

2 Barnard and Karaman (1984).

3 Wilson and Wägele (1994) 
Table 4 Distribution of stygofauna in New South Wales and Tasmanian karsts ${ }^{1}$. The stygobite category excludes possible stygobites or taxa with an uncertain ecological classification. Highest totals for each category are shown in bold. Region names for the IBRA codes are given in Table 1.

\begin{tabular}{|c|c|c|c|c|c|c|c|c|}
\hline \multirow[b]{2}{*}{ Category } & \multicolumn{4}{|c|}{ New South Wales } & \multicolumn{4}{|c|}{ Tasmania } \\
\hline & NNC & NSS & SEH & AA & WOO & WSW & DE & FRE \\
\hline No. karst areas per region containing stygofauna & 6 & 5 & 15 & 2 & 9 & 13 & 9 & 1 \\
\hline Total no. species per region & 13 & 10 & 56 & 12 & 46 & 55 & 45 & 3 \\
\hline No. stygobites & 3 & 9 & 21 & 3 & 14 & 19 & 16 & 2 \\
\hline
\end{tabular}

1 Data based on the New South Wales Cave Invertebrate database (Eberhard and Spate, 1995) and Tasmanian RFA database (Clarke, 1997), and recent unpublished records.

more stygobitic taxa. This includes Exit Cave (10 stygobites) and Arthur's Folly Cave (14 stygobites) at Ida Bay and Hardy Cave (13 stygobites) at Loongana (Clarke, 1997).

A low abundance of stygofauna is also typical of most Eastern Australian caves, and may relate to limited food supplies (Jasinska and Knott, 2000). However, high abundances have been reported from those caves that contain aquatic root mats, a substantial and reliable food source. This includes caves from Stockyard Creek, Timor, Wellington, Abercrombie and Wombeyan in New South Wales, and Mole Creek in Tasmania (Eberhard and Spate, 1995; Jasinska and Knott, 2000).

\section{DISTRIBUTION PATTERNS OF STYGOFAUNA}

\section{Geographic distribution patterns}

The broad distribution patterns of stygofauna across the IBRA regions is summarised in Table 1. Most taxa are concentrated in regions in New South Wales and Tasmania. Biases in research effort may have resulted in the apparent focus of diversity within these two States. The karsts of Victoria and southeastern South Australia have only been sparsely surveyed (Hamilton-Smith and Eberhard, 2000). The stygofauna of Queensland is also poorly known, although intensive surveys at Chillagoe and Undara in the Einasleigh Uplands have located several amphipods (Barnard and Williams 1995; J. Bradbury, personal communi-cation, 2000).

Table 4 shows that the distribution of stygofauna in New South Wales and Tasmania is concentrated in the highland areas where karst development is greatest. In Tasmania this includes karsts in the Woolnorth, West and South West and $D^{\prime}$ Entrecasteaux Regions, all of which support similar levels of stygobite richness. In New South Wales, the stygofauna is concentrated in karsts of the South East Highlands Region.

The overall diversity of stygofauna in New South Wales (83 taxa) is lower than that of Tasmania (98 taxa). Tasmania also has a greater diversity amongst the higher order Crustacea, with 49 taxa from 18 genera and 11 families, while New South Wales contains 36 taxa from 15 genera and seven families. The composition of the Tasmanian stygofauna is also distinct from that of New South Wales at both the generic and species level (Table 1). The number of confirmed stygobites is similar (32 versus 33 taxa respectively) between these States. Stygobites, stygophiles and epigean species each make up one third of the groundwater fauna in Tasmania, while in New South Wales, stygobites account for $43 \%$ of the fauna.

\section{Taxonomic distribution patterns}

\section{Amphipoda}

Amphipods have the broadest distribution pattern of all crustacean stygofauna in Eastern Australia (J. Bradbury, personal communication, 1999). They are well represented in the karsts of New South Wales and Tasmania and are the only described stygofauna from North Queensland. Overall, Paramelitidae dominates the amphipods and includes 35 stygobite species from eight genera (Table 5). The highest diversity ( $77 \%$ of taxa) of paramelitids are found in Tasmania.

Several paramelitids have a very localised distribution and are only known from hypogean forms. This includes Uronyctus longicaudus Stock and Iliffe, 1990 from the Naracoorte Coastal Plain and Chillagoe thea Barnard and Williams, 1995 from the Einasleigh Uplands. Antipodeus is restricted to Tasmania but is widespread in the surface and hypogean waters of that State. The remaining described paramelitids (Table 5) have a broadly scattered distribution in the surface waters of southeastern Australia, but it is only in Tasmania that they form part of the stygofauna.

Neoniphargid amphipods are endemic to Australia (Bradbury and Williams, 1997a), and the stygofauna includes nine genera and 23 species. Eighty-seven percent of stygal species are restricted to the karsts of New South Wales, the rest occurring in Tasmania. In New South Wales the family occurs in all four IBRA regions but the greatest diversity is found in the South East Highlands (Table 5), where most genera and species have an extremely localised distribution. In Tasmania they occur in the Woolnorth, West and South West Regions. 
Table 5 Regional distribution of stygal paramelitid and neoniphargid amphipod genera from Eastern Australia ${ }^{1}$. Region codes are provided in Table 1.

\begin{tabular}{|c|c|c|c|c|c|c|c|c|c|c|}
\hline \multirow{2}{*}{$\begin{array}{l}\text { IBRA region } \\
\text { TAXA }\end{array}$} & \multirow{2}{*}{$\begin{array}{c}\text { Queensland } \\
\text { EIU }\end{array}$} & \multicolumn{4}{|c|}{ New South Wales } & \multirow{2}{*}{$\begin{array}{c}\text { South Australia } \\
\text { NCP }\end{array}$} & \multicolumn{4}{|c|}{ Tasmania } \\
\hline & & NNC & NSS & SEH & $\mathbf{A A}$ & & WOO & WSW & DE & FRE \\
\hline \multicolumn{11}{|l|}{ Paramelitidae $^{2}$} \\
\hline Chillagoe & - & & & & & & & & & \\
\hline Uronyctus & & & & & & $\bullet$ & & & & \\
\hline Austrogammarus & & & & & & - & - & - & & \\
\hline Antipodeus & & & & & & & - & & - & \\
\hline Austrocrangonyx & & & & & & & $\bullet$ & & - & \\
\hline Giniphargus & & & & & & & & - & & \\
\hline Austrochiltonia & & & & & & & - & & & \\
\hline Genus near Hurleya & & & & & & & - & - & - & - \\
\hline Genus near Giniphargus & & & & & & & & $\bullet$ & & \\
\hline \multicolumn{11}{|l|}{ Neoniphargidae $^{3}$} \\
\hline Neoniphargus & & & & - & $\bullet$ & & - & - & & \\
\hline Neocrypta & & & $\bullet$ & - & & & & & & \\
\hline Jasptorus & & & & - & & & & & & \\
\hline Wombeyanus & & & & $\bullet$ & & & & & & \\
\hline Gen. nov. 1 & & & & - & & & & & & \\
\hline Gen. nov. 2 & & - & & - & & & & & & \\
\hline Gen. nov. 3 & & & & - & & & & & & \\
\hline Gen. nov. 4 & & & & - & & & & & & \\
\hline Gen. nov. 5 & & & & - & & & & & & \\
\hline Genus undetermined & & & $\bullet$ & - & & & & & & \\
\hline
\end{tabular}

1 Based on the New South Wales Cave Invertebrate database (Eberhard and Spate, 1995), Tasmanian RFA database (Clarke, 1997), and recent unpublished records.

2 Tasmanian paramelitid stygofauna are currently being revised by J. Bradbury.

3 The undescribed neoniphargid genera were identified by J. Bradbury (personal communication, 1995).

Neoniphargus is the most widely distributed neoniphargid genus in Eastern Australia, but this distribution pattern is highly disjunct. Most are stygobitic species endemic to a single karst area occurring in the South East Highlands, Australian Alps, or West and South West Regions. N. obrieni Nicholls, 1926b is the only described stygophile and has been collected from surface waters at Mount Buffalo in Victoria (Bradbury and Williams, 1997b). There are two significant enterable caves at Mount Buffalo, so it is possible that this genus also occurs in hypogean waters (E. Hamilton-Smith, personal communication, 2000). Apart from Neoniphargus, all other neoniphargid genera are restricted to $\mathrm{New}$ South Wales (Table 5), and most of these are only found at Wombeyan Caves.

\section{Syncarida}

Syncarids consist of two extant orders, the Bathynellacea and the Anaspidacea. Bathynellaceans are present in interstitial waters across Eastern Australia but have been largely overlooked in hypogean waters (P. Serov, unpublished data). Three families of Anaspidacea have been recorded from Eastern Australia and all are endemic to the south east of the continent (Table 6), having not been found north of New South Wales (P. Serov, unpublished data).

Tasmania contains the greatest taxonomic diversity of anaspids, with five genera and up to nine species. Included are a mixture of stygobites and stygophiles, half of which are local endemics, the remainder occurring across two or more karst areas. Eucrenonaspides, Micraspides and Anaspides do not occur in groundwaters of the mainland, and in Tasmanian karsts they are often syntopic (Eberhard et al., 1991). Anaspides tasmaniae Thomson, 1893 is widespread with a predominantly surface distribution. Subterranean populations are found mostly in the D'Entrecasteaux and West and South West Regions. The cave taxa form a complex of morphospecies containing both stygophiles and stygobites (A. Clarke, unpublished data). Caves may have been glacial refuges for this species as it occurs in areas formerly subjected to repeated cycles of glaciation (Kiernan, 1990).

Koonunga is the only syncarid genus found both in Tasmania and on the mainland. Epigean forms of Koonunga are scattered widely in surface waters of New South Wales, South Australia and Victoria. Hypogean species are restricted to single karst areas in both the Woolnorth Region of Tasmania and the South East Highlands of New South Wales (A. Clarke, unpublished data; P. Serov, unpublished data).

The stygobite $K$. crenarum Zeidler, 1985 is widespread in the waters of the southern 
Table 6 Regional distribution of stygal anaspid syncarid genera from Eastern Australia ${ }^{1}$. For region codes see Table 1.

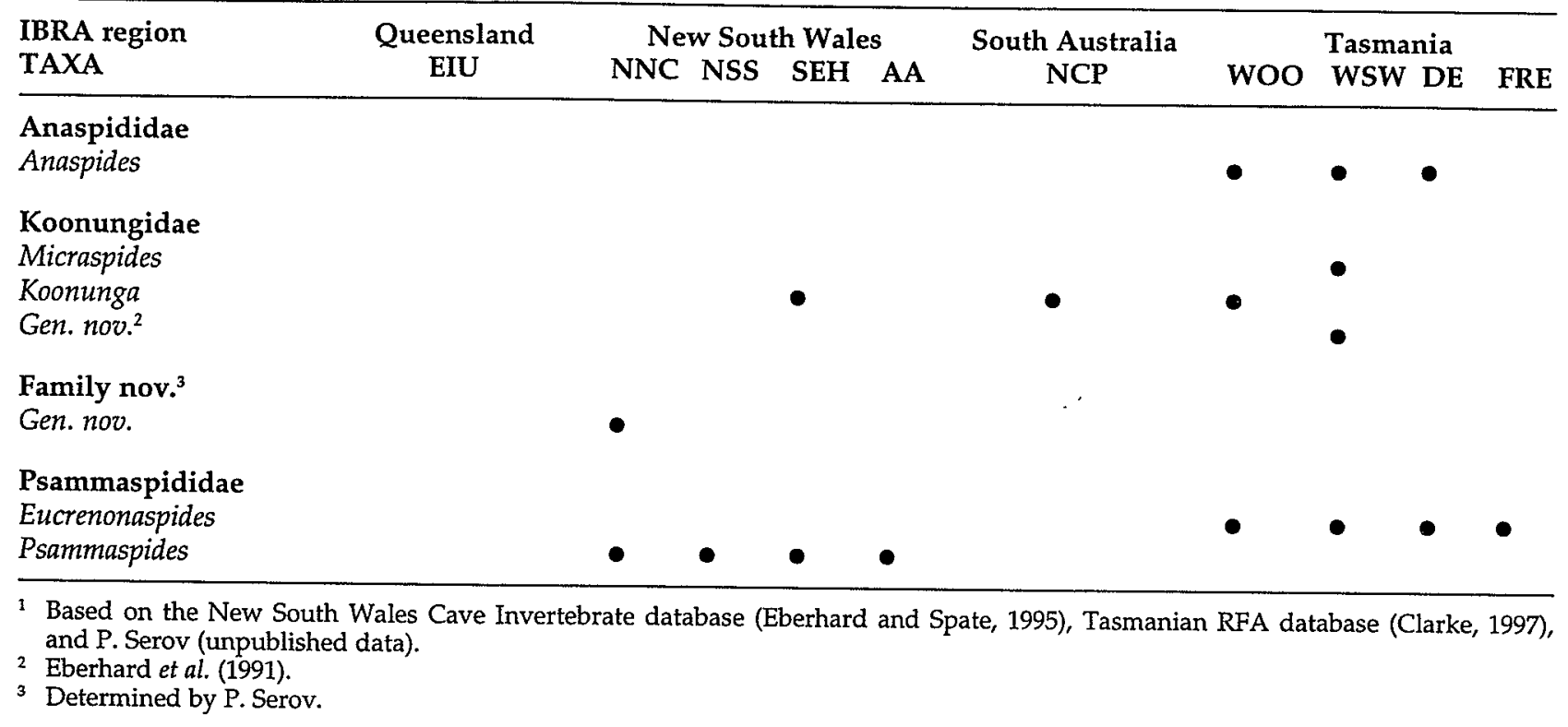

Naracoorte Coastal Plain. This Region has been subjected to many marine transgressions, both during the Cretaceous and throughout the Quaternary (Schwebel, 1983). Preferring cool, permanent freshwater environments ( $P$. Serov, unpublished data), $K$. crenarum may have avoided the marine transgressions by inhabiting groundwaters in the north of the region, later dispersing to its present southern distribution by following surface groundwater discharges. Subterranean dispersal is unlikely as there are no continuous fracture systems between the northern and southern karsts, and $K$. crenarum is too large for interstitial travel (Zeidler, 1985).

Two congeneric species of an undescribed anaspid family occur in caves and interstitial waters of the North Coast Region in New South Wales and they are considered to have close affinities with Koonungidae (P. Serov, unpublished data). Both species possess specialised raptorial grasping appendages and are probably active predators (Eberhard and Spate, 1995), in contrast to most other syncarids that are omnivorous detritivores (P. Serov and S. Eberhard, unpublished data).

The dominant syncarid genus in New South Wales is Psammaspides, which occurs in five karst areas in the South East Highlands, four areas in the West and South West and one in the Australian Alps. Each species occurs in a single karst area, and often only in one cave. All are stygobites (all undescribed), and are considered phylogenetic and distributional relicts (Eberhard and Spate, 1995). In addition, $P$. williamsi Schminke, 1974, an interstitial species, occurs in the North Coast Region of New South Wales.

\section{Isopoda}

Eastern Australian subterranean isopods are less speciose than the amphipods and syncarids, and are more restricted in distribution. The Janiridae and Phreatoicidae dominate the isopod stygofauna of Tasmania and New South Wales. The majority of the stygal isopods from Eastern Australia are completely undetermined.

The janirids are represented by the genus Heterias and are found in the Australian Alps and South Western Slopes in New South Wales, and all regions in Tasmania except Freycinet. The phreatoicids include at least three genera and five species. In Tasmania, phreatoicids have a patchy distribution and are found in karst groundwaters on the western side of the State. Stygal phreatoicids in New South Wales all belong to the genus Crenoicus, which has a broad distribution in epigean environments (Wilson and Ho, 1996). Hypogean populations of Crenoicus are restricted to two karst areas in the South East Highlands Region.

\section{Mollusca}

Tasmania has an outstandingly rich subterranean molluscan fauna (25 taxa), especially of hydrobiid gastropods. Twenty-two hydrobiid species from six genera are found in karst areas of the Woolnorth, West and South West and D'Entrecasteaux Regions, of which seven are probably stygobites. Recent research suggests that 12 stygobitic hydrobiids from Precipitous Bluff may be added to the current total (W. Ponder, personal communication, 1999). This combined level of diversity compares favourably with 28 species of obligate subterranean molluscs known from the much larger landmass of the 48 contiguous United States (Culver et al., 2000). 
The molluscan stygal diversity in mainland karsts is very low and probably reflects a more variable moisture and climate regime than is present in Tasmania. At least four genera from three families occur in groundwaters of the Naracoorte Coastal Plain Region but there are no obligate species present. Two genera from this region, Angrobia and Miselaoma are shared with Tasmania. The fauna of New South Wales includes at least one obligate species of Austropyrgus (W. Ponder, personal communication, 1999). Other stygal molluscs from New South Wales are concentrated into several karsts in the South East Highlands and Australian Alps Regions.

\section{Overall distribution patterns}

From an examination of the molluscs and higher crustaceans of Tasmania and New South Wales, several dominant distribution patterns are evident. The Tasmanian stygofauna includes species with both localised and broad distribution patterns, and roughly equal proportions of stygobites and stygophiles are present. Taxonomic diversity is high overall in Tasmania and there is considerable speciation across the Paramelitidae and Hydrobiidae (Eberhard et al., 1991; Eberhard and Spate, 1995).

In New South Wales the stygofauna are highly localised in distribution (most species are stygobites endemic to one karst area), and few stygophiles are present. The Neoniphargidae and Psammaspididae comprise the bulk of the taxonomic diversity displaying high generic and species diversity. These differences in distribution patterns between the two States may relate to differences in available habitat, present climate and past vicariant events.

\section{DIVERSITY AND DISTRIBUTION OF STYGOFAUNA AT WOMBEYAN CAVES}

We now present a case study of the stygofauna at Wombeyan Caves, New South Wales to more closely examine diversity and distribution patterns within a single karst area. In the context of mainland Eastern Australia, the stygofaunal diversity at Wombeyan is very high. The South Eastern Highlands Region supports two-thirds of the stygofauna of New South Wales, and half of this total is concentrated at Wombeyan Caves. This includes $43 \%$ of the stygal neoniphargid taxa of Eastern Australia, most of these being endemic to Wombeyan.

Wombeyan Caves are described in detail in Dyson et al. (1982). Most of the karst is contained within the boundaries of the Wombeyan Karst Conservation Reserve. The karst originated as a single lens of Silurian limestone, and in the early Devonian period the limestone was covered by volcanic rocks and modified into a fractured crystalline marble (James et al., 1982). The karst has a surface extent of $4.13 \mathrm{~km}^{2}$ and is surrounded by igneous rocks. The reserve boundaries, major surface streams, and location of sites containing stygofauna are shown in Figure 3.

The hydrology of the Reserve is complex and comprises a number of subterranean catchments (James et al., 1982; T. Dennis, personal communication, 1993) as shown in Figure 3. On the southern side of Mares Forest Creek, Fred Cave and Marble Sewer Spring may be part of the Gap Creek catchment, but hydrological connections have not been clearly established (T. Dennis, personal communication, 1993). The waters within Basin Cave appear to form a perched water table (M. Chalker, personal communication, 1999).

The northern side of Mares Forest Creek is more complex. Glass, River and Gu-rang-atch Caves form part of the subterranean drainage for Oakey Range Creek catchment. All other sites shown in Figure 3 are part of the Wombeyan Creek catchment, which includes a number of drainage systems. Bullio Cave and Mares Forest Creek Cave form part of the Right Bank Drainage Complex, while the Junction-Figtree system, Grants Cave and W78 are part of the Left Bank Drainage Complex.

Table 7 provides a summary of taxa that have been collected from 14 caves at Wombeyan. Half of the stygofauna are crustaceans comprising neoniphargid amphipods (10 taxa, all stygobites), as well as syncarids, decapods and copepods. In addition, gastropods, insects, nemertineans, oligochaetes and turbellarians are present. Recently protozoans have been collected from Wombeyan Caves, and as many as 20 ciliate forms may be present (M.E. Thurgate and J.S. Gough, unpublished).

Each of the catchments contains a distinctive fauna (Table 7). The Basin Cave 'catchment' is the only location where syncarids have been found. Stygobitic amphipods occur in all catchments, but each cave contains one or two species endemic to that cave (Eberhard and Spate, 1995; J. Bradbury, personal communication, 1999). The Oakey Range Creek catchment is particularly rich in this fauna (five taxa). Gastropods (three taxa) occur in four catchments, and are concentrated in caves closest to Mares Forest Creek, the only perennial watercourse on the Reserve (Figure 3).

The distribution of stygofauna in the Left Bank Drainage Complex is interesting because it reflects the presence of two drainage systems within the complex (T. Dennis, personal communication, 1993). Stygoxenes (insects and gastropods) dominate the drainage system containing the Junction-Figtree system, and no stygobites are present. In contrast, stygobitic amphipods dominate Grants Cave and W78, which are found in the second drainage system. 


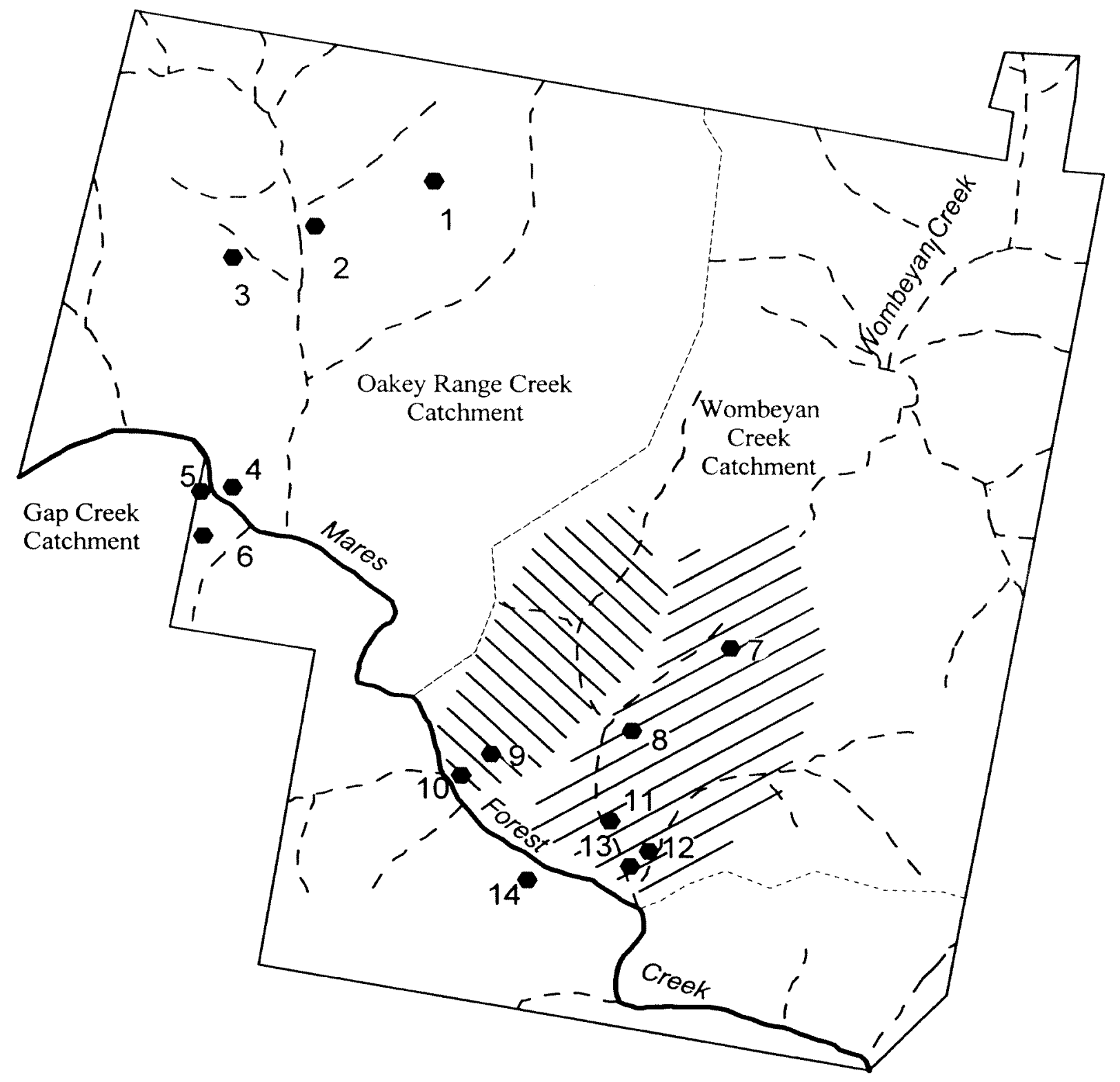

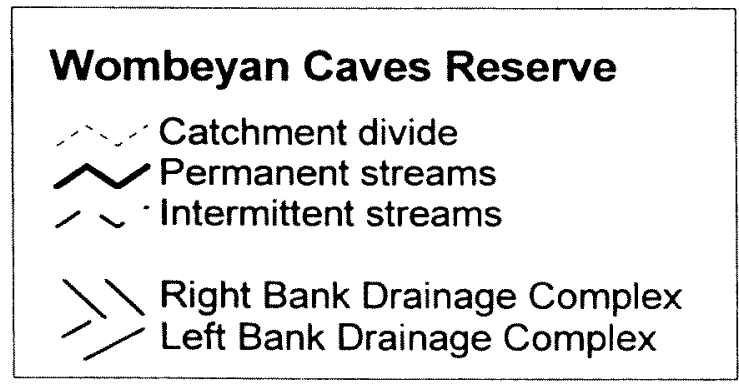
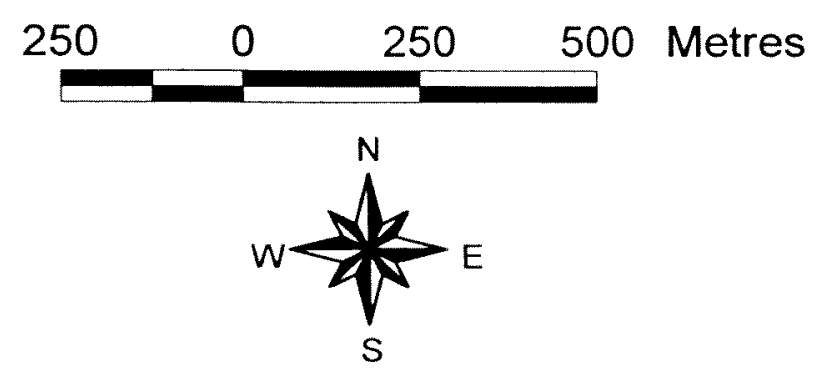

\section{Key to Caves}

$\begin{array}{ll}1 & \text { Glass Cave } \\ 2 & \text { River Cave } \\ 3 & \text { Gu-rang-atch } \\ 4 & \text { River Cave Spring } \\ 5 & \text { Fred Cave } \\ 6 \text { Marble Sewer Spring } \\ 7 \text { Fig Tree Cave } \\ 8 \text { Grants Cave } \\ 9 \text { Bullio Cave } \\ 10 \text { Mares Forest Creek Cave } \\ \text { Spring } \\ 11 \text { W } 78 \\ 12 \text { Junction Cave } \\ 13 \text { Junction Cave Spring } \\ 14 \text { Basin Cave }\end{array}$

Figure 3 Map of Wombeyan Karst Conservation Reserve showing the location of subterranean catchments (as determined by T. Dennis, personal communication, 1993) and sites containing stygofauna. The shaded sections represent subterranean drainage systems of Wombeyan Creek. 
Table 7 List of stygofauna occurring at Wombeyan Caves ${ }^{1}$. The shaded taxa represent the neoniphargid amphipod species found to date. Cave sites have been arranged according to catchments. Cave site codes are shown in Figure 3. Abbreviations are as follows: $\mathrm{LBDC}=$ Left Bank Drainage Complex, $\mathrm{RDBC}=$ Right Bank Drainage Complex, $\mathrm{BC}=$ Basin Cave.

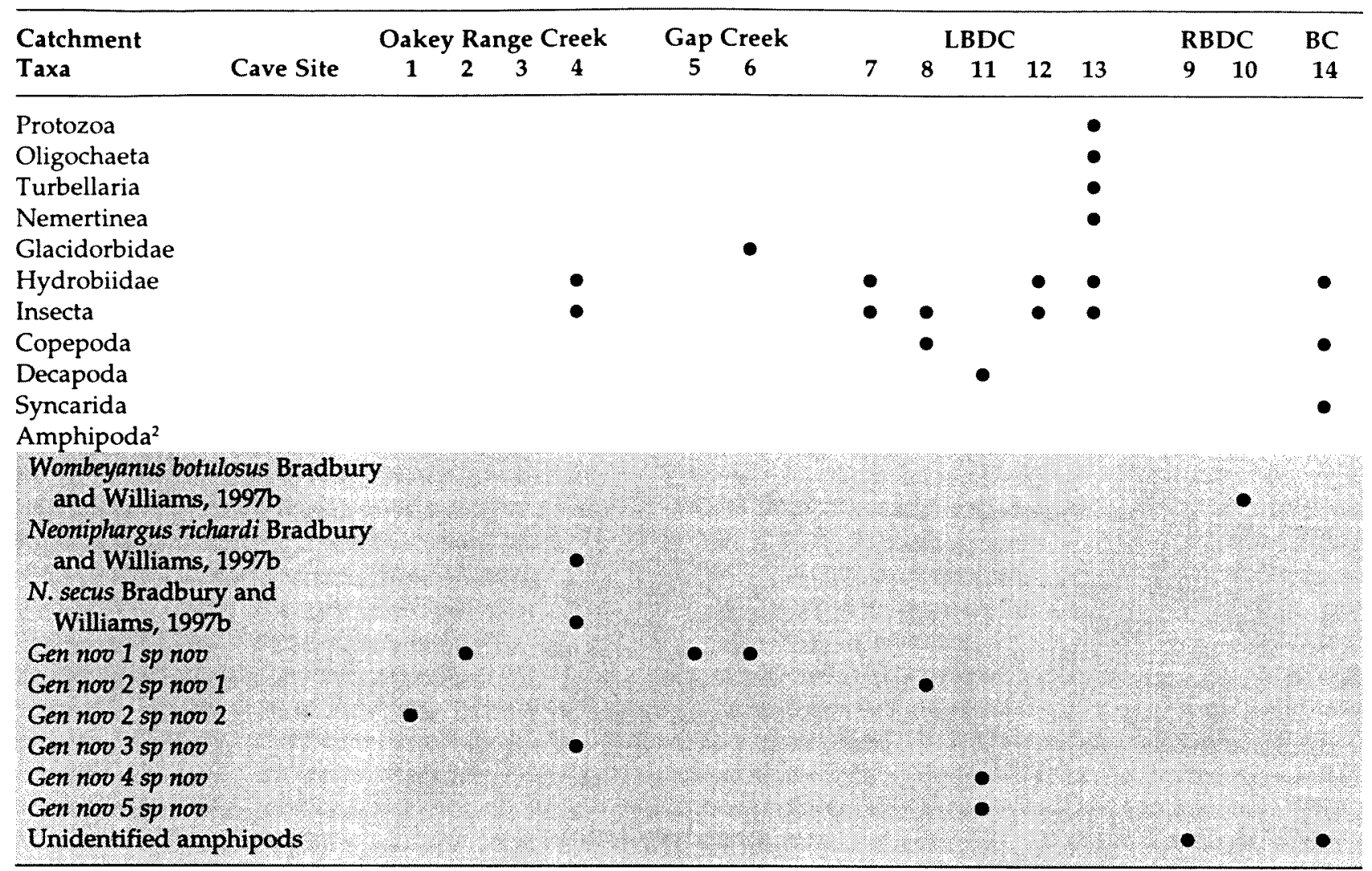

1 New South Caves Cave Invertebrate database (Eberhard and Spate, 1995) and M.E. Thurgate and J.S. Gough (unpublished data).

2 New genera and species identified by J. Bradbury (personal communication, 1995).

There are a number of factors that may contribute to Wombeyan Caves' high stygofauna diversity and peculiar distribution patterns. Wombeyan is one of the most cavernous karst areas in New South Wales, and has been subjected to three or four periods of karstification since the Devonian (Osborne, 1993). As part of this process, the caves have been subjected to burial and infilling at various times, promoting the blockage and diversion of groundwater flows leading to the development of the complex hydrology described above. The resulting isolation of cave systems may have contributed to the distinctive faunal patterns between catchments.

\section{CONCLUSIONS AND FUTURE DIRECTIONS}

The stygofauna of Eastern Australia contributes a significant component of the subterranean biodiversity of the continent. The fauna is of great significance for it includes many obligate and locally endemic species, as well as species with Gondwanan and Pangaean affinities. Further study of this stygofauna may provide vital information for understanding the evolutionary history of the continent and of individual karst areas.
To some extent this paper is premature as stygofauna research in Eastern Australia is still in its infancy. Most collections have been made incidental to surveys of terrestrial cave communities and many areas have not yet been examined. A species list from a single visit to a few caves is often the full extent of available knowledge of the stygofauna for a karst area. Taxonomic knowledge is also very poor for most groups, but is gradually improving.

We suggest that three main areas deserve increased research effort. Firstly, gaps in taxonomic knowledge need to be addressed. Current information suggests that the diversity of these communities is high, but current diversity estimates are imprecise, as final determinations are lacking for most taxa. Before further surveys are undertaken, we suggest that a priority should be to identify the fauna that has already been collected, and that the crustaceans (as the dominant group) should initially be the primary focus.

Secondly, distribution patterns should be mapped to further biogeographical studies, to provide a means of predicting species distributions and to prioritise sites to target in future surveys. Our 
information suggests that New Guinea Ridge, Limestone Creek, Buchan and Murrindal in Victoria; Indi and many places in the Central West of New South Wales; Camooweal and MitchellPalmer in Queensland, and Naracoorte in South Australia should be targeted in future survey efforts. The hyporheic fauna of Victorian and South Australian peat swamps (adjacent to or overlying karst) and alluvial aquifers deserve attention, particularly where syncarids are already known. Epigean and hypogean habitats should be surveyed simultaneously to assist in determining which of the stygofauna are obligate to groundwaters.

Finally, improved management and conservation can only be achieved with better understanding of whole ecosystems. More information is needed about the environments in which stygofauna occur, and the interactions of species within these environments. Collecting data about the physiochemistry of different sites, the fine-scale distribution patterns of stygofauna, the dietary preferences of species and the sensitivity of taxa to disturbance or degradation is vitally important for gaining a better understanding of stygal ecosystems.

\section{ACKNOWLEDGEMENTS}

We acknowledge the outstanding efforts of Stefan Eberhard in the field of stygofauna research in Eastern Australia. Kevin Kiernan, Todd Dennis and Armstrong Osborne are acknowledged for their contributions to karst geomorphology and hydrology, which are integral to understanding faunal distribution patterns. Stefan Eberhard, Buz Wilson, John Bradbury and Winston Ponder provided information about the taxonomy, distribution and significance of the fauna. We thank Alexander Herr and Alastair Richardson for comments on early drafts of the manuscript, and our reviewers whose comments greatly enhanced the final paper. Lynette Finch assisted with the preparation of the maps.

\section{REFERENCES}

Banarescu, P. (1990a). Zoogeography of fresh waters: general distribution and dispersal of freshwater animals: volume 1. AULA-Verlag, Wiesbaden.

Banarescu, P. (1990b). Zoogeography of fresh waters: distribution and dispersal of freshwater animals in Africa, Pacific areas and South America: volume 3. AULAVerlag, Wiesbaden.

Barnard, J.L. and Karaman, G.S. (1984). Australia as a major evolutionary centre for Amphipoda (Crustacea). Memoirs of the Australian Museum 18: 4561.

Barnard, J.L. and Williams, W.D. (1995). The taxonomy of Amphipoda (Crustacea) from Australian fresh waters: Part 2. Records of the Australian Museum 47: $161-201$
Botosaneanu, L. (ed). (1986). Stygofauna Mundi: a faunistic, distributional and ecological synthesis of the World fauna inhabiting subterranean waters (including the marine interstitial). E.J. Brill/Dr. W. Backhuys, Leiden, The Netherlands.

Bradbury, J.H. (2000). Western Australian stygobiont amphipods (Crustacea: Paramelitidae) from the $\mathrm{Mt}$ Newman and Millstream regions. Records of the Western Australian Museum Supplement 60: 1-102.

Bradbury, J.H. and Williams, W.D. (1997a). Amphipod (Crustacea) diversity in underground waters in Australia: an Aladdin's Cave. Memoirs of the Museum of Victoria 56: 513-519.

Bradbury, J.H. and Williams, W.D. (1997b). The amphipod (Crustacea) stygofauna of Australia: description of new taxa (Melitidae, Neoniphargidae, Paramelitidae), and a synopsis of known species. Records of the Australian Museum 49: 249-341.

Clarke, A. (1995). Searching for palaeokarst at Ida Bay in southern Tasmania. Speleo Spiel 287: 4-10.

Clarke, A. (1997). Management prescriptions for Tasmania's cave fauna. Report to the Tasmanian RFA Environment and Heritage Technical Committee, Hobart.

Culver, D.C., Master, L.L., Christman, M.C. and Hobbs, H.H. (2000). Obligate cave fauna of the 48 contiguous United States. Conservation Biology 14: 386-401.

Culver, D.C. and Sket, B. (2000). Hotspots of subterranean biodiversity in caves and wells. Journal of Cave and Karst Studies 62: 11-17.

Dyson, H.J., Ellis, R. and James, J.M. (eds). (1982). Wombeyan Caves. Sydney Speleological Society, Sydney.

Eberhard, S.M., Richardson, A.M.M. and Swain, R. (1991). The Invertebrate cave fauna of Tasmania. Zoology Department, University of Tasmania, Hobart.

Eberhard, S.M. and Spate, A. (1995). Cave invertebrate survey: towards an atlas of NSW cave fauna. Report to the Department of Urban Affairs and Planning and the Australian Heritage Commission, Canberra.

Gibert, J., Danielopol, D.L. and Stanford, J.A. (eds). (1994). Groundwater ecology. Academic Press, San Diego.

Hamilton-Smith, E. and Eberhard, S. (2000). Conservation of cave communities in Australia. In Wilkens, H., Culver, D.C. and Humphreys, W.F. (eds), Ecosystems of the world, Volume 30: Subterranean ecosystems: 647-664. Elsevier, Amsterdam.

Holsinger, J.R. (1993). Biodiversity of subterranean amphipod crustaceans: global patterns and zoogeographic implications. Journal of Natural History 27: 821-835.

Humphreys, W.F. (2000a). The hypogean fauna of the Cape Range Peninsula and Barrow Island, Northwestern Australia. In Wilkens, H., Culver, D.C. and Humphreys, W.F. (eds), Ecosystems of the world, Volume 30: Subterranean ecosystems: 581-601. Elsevier, Amsterdam.

Humphreys, W.F. (2000b). Background and glossary. In Wilkens, H., Culver, D.C. and Humphreys, W.F. (eds), Ecosystems of the world, Volume 30: Subterranean ecosystems: 3-14. Elsevier, Amsterdam. 
Humphreys, W.F. (2000c). Relict faunas and their derivation. In Wilkens, H., Culver, D.C. and Humphreys, W.F. (eds), Ecosystems of the world, Volume 30: Subterranean ecosystems: 417-432. Elsevier, Amsterdam.

Humphreys, W.F. (2001). Groundwater calcrete aquifers in the Australian arid zone: the context to an unfolding plethora of stygal biodiversity. Records of the Western Australian Museum, Supplement No. 64: 63-83.

James, J.M., Jennings, J.N., Martyn, M. and Halbert, E.J. (1982). Investigating surface and underground water. In Dyson, H.J., Ellis, R. and James, J.M. (eds), Wombeyan Caves: 65-82. Sydney Speleological Society, Sydney.

Jasinska, E.J. and Knott, B. (2000). Root-driven faunas in cave waters. In Wilkens, H., Culver, D.C. and Humphreys, W.F. (eds), Ecosystems of the world, Volume 30: Subterranean ecosystems 287-307. Elsevier, Amsterdam.

Jennings, J.N. (1982). Karst of northeastern Queensland reconsidered. Tower Karst 4: 13-52.

Kiernan, K. (1990). The extent of late Cainozoic glaciation in the central Highlands of Tasmania. Arctic and Alpine Research 22: 341-354.

Kiernan, K. (1995). An atlas of Tasmanian karst. Tasmanian Forest Research Council, Hobart.

Knott, B. (1986). Isopoda: Phreatoicidea. In Botosaneanu, L. (ed), Stygofauna Mundi: a faunistic, distributional and ecological synthesis of the world fauna inhabiting subterranean waters (including the marine interstitial): 486-492. E.J. Brill/Dr. W. Backhuys, Leiden.

Osborne, R.A.L. (1993). The history of karstification at Wombeyan Caves, New South Wales, Australia, as revealed by palaeokarst deposits. Cave Science 20: 1-8.

Osborne, R.A.L. (1999). The origin of Jenolan Caves: elements of a new synthesis and framework chronology. Proceedings of the Linnean Society of New South Wales 121: 1-27.

Osborne, R.A.L. and Branagan, D.F. (1988). Karst landscapes of New South Wales, Australia. Earth Science Reviews 25: 467-480.

Schwebel, D.A. (1983). Quaternary dune systems. In Tyler, M.J., Twidale, C.R., Ling, J.K. and Holmes, J.W. (eds), Natural history of the South East: 15-24. Royal Society of South Australia Inc., Northfield, Adelaide.

Sket, B. (1999). High biodiversity in hypogean waters and its endangerment - the situation in Slovenia, the Dinaric Karst and Europe. Crustaceana 72: 767-779.

Thackway, R. and Cresswell, 1.D. (1995). An interim biogeographical regionalisation for Australia: A framework for setting priorities in the National Reserves System Cooperative Program. Australian Nature Conservation Agency, Canberra.

Thurgate, M.E. (1995). Sinkholes, caves and spring lakes: an introduction to the unusual aquatic ecosystems of the Lower South East of South Australia. Occasional Paper Number 1. South Australian Underwater Speleological Society, Adelaide.

Williams, W.D. (1986). Amphipoda on land-masses derived from Gondwana. In Botosaneanu, L. (ed), Stygofauna Mundi: a faunistic, distributional and ecological synthesis of the world fauna inhabiting subterranean waters (including the marine interstitial): 553-559. E.J. Brill/Dr. W. Backhuys, Leiden.

Williams, W.D. and Barnard, J.L. (1988). The taxonomy of crangonyctoid Amphipoda (Crustacea) from Australian fresh waters: foundation studies. Records of the Australian Museum Supplement 10: 1-180.

Wilson, G.D.F. and Ho, E.L. (1996). Crenoicus Nicholls, 1944 (Crustacea, Isopoda, Phreatoicidea): systematics and biology of a new species from New South Wales. Records of the Australian Museum 48: 7-32.

Wilson, G.D.F. and Johnson R.T. (1999). Ancient endemism among freshwater isopods (Crustacea, Phreatoicidea). In Ponder, W. and Lunney, D. (eds), The Other $99 \%$. The Conservation and Biodiversity of Invertebrates: 264-268. Royal Zoological Society of New South Wales, Mosman.

Wilson, G.D.F. and Wägele, J. W. (1994). Review of the family Janiridae (Crustacea: Isopoda: Asellota). Invertebrate Taxonomy 8: 683-747.

Zeidler, W. (1983). Freshwater and some terrestrial invertebrates. In Tyler, M.J., Twidale, C.R., Ling, J.K. and Holmes, J.W. (eds), Natural history of the South East: 187-204. Royal Society of South Australia Inc., Northfield, Adelaide.

Zeidler, W. (1985). A new species of crustacean (Syncarida: Anaspidacea: Koonungidae) from the sinkholes and caves of the South-East of South Australia. Transactions of the Royal Society of South Australia 109: 63-75.

Manuscript received 1 July 2000; accepted 5 February 2001. 